\title{
REG4 expression was a potential marker for carcinogenesis, aggressiveness and prognosis of gastric cancer: a meta and bioinformatics analysis
}

\author{
Hua-Chuan Zheng ${ }^{1}$, Jing $\mathrm{Li}^{2}$ and Shuang Zhao ${ }^{1}$ \\ ${ }^{1}$ Department of Experimental Oncology, Shengjing Hospital of China Medical University, Shenyang 110004, China \\ ${ }^{2}$ Department of Gastroenterology, The First Affiliated Hospital of Jinzhou Medical University, Jinzhou 121001, China \\ Correspondence to: Hua-Chuan Zheng, email: zheng_huachuan@hotmail.com
}

Keywords: REG4; gastric cancer; meta analysis; bioinformatics analysis

Received: July 05, 2017 Accepted: December 15, $2017 \quad$ Published: January 05, 2018

Copyright: Zheng et al. This is an open-access article distributed under the terms of the Creative Commons Attribution License 3.0 (CC BY 3.0), which permits unrestricted use, distribution, and reproduction in any medium, provided the original author and source are credited.

\section{ABSTRACT}

REG4 is a potent activator of EGFR/Akt/AP-1 signaling pathway, and a potential marker for mucin-producing carcinoma and neuroendocrine tumors. Here, we performed a systematic meta and bioinformatics analysis through multiple online databases up to March 14, 2017. We found up-regulated REG4 expression in gastric cancer, compared with normal mucosa $(p<0.05)$. REG4 expression was positively with depth of invasion, lymph node metastasis, TNM staging and dedifferentiation of gastric cancer $(p<0.05)$. According to bioinformatics databases, REG4 mRNA expression was higher in gastric cancer than normal tissues $(p<0.05)$, and negatively correlated with histological grading of gastric cancer $(p<0.05)$. According to Kaplan-Meier plotter, we found that a higher expression of REG4 mRNA was positively correlated with overall and progression-free survival rates of the cancer patients with diffuse-type and N1-3 cancers or undergoing other adjuvant $(p<0.05)$, but versa for the M1 cancers $(p<0.05)$. These findings indicated that REG4 expression might be employed as a potential marker to indicate gastric carcinogenesis and subsequent progression, even prognosis.

\section{INTRODUCTION}

Regenerating (Reg) gene family belongs to the calcium-depending lectin gene super family, and its encoding protein acts as acute phase reactants, lectins, anti-apoptotic or growth agents [1]. REG4 is a potent activator of EGFR/Akt/ AP-1 signaling pathway, and a potential marker for mucinproducing carcinoma and neuroendocrine tumors [2-4]. SP1, GATA6 and CDX2 are proved to be transcription factors of $R E G 4$ gene, which is essential for cellular proliferation and tumorigenesis [5-7]. Bishnupuri et al. [8] found that REG4induced mitogenesis was activated by Akt-GSK3 $\beta$ - $\beta$-cateninTCF-4 signaling in colorectal cancer. REG4 also induced the expression of MMP-7 and MMP-9, which contributed to invasion of pancreatic cancer cells [9]. The pancreatic cancer secreted REG4, which promoted macrophage polarization to M2 through EGFR/Akt/CREB pathway [10].

Nanakin et al. [11] found that strong REG4 mRNA was strongly expressed in inflamed epithelium, dysplasia and cancerous lesions of ulcerative colitis tissues, and correlated with the mRNA expression of $b F G F$ and $H G F$ that subsequently stimulated REG4 expression in colon cancer cells [12]. REG4 mRNA was overexpressed in colorectal, and pancreatic, hepatocellular and prostate cancers [13-17]. Recently, it has been reported that $R E G 4$ overexpression induces the phosphorylation of the EGFR and inhibits 5-fluorouracil- induced apoptosis in gastric cancer cells [18]. Our previous work showed that REG4 expression should be considered as a good biomarker for gastric intestinal metaplasia and dysplasia, and was especially related to the histogenic pathway of signet ring cell carcinoma [19]. Here, a meta- and bioinformatics analysis was carried out to explore the clinicopathological and prognostic significances of REG4 expression in gastric cancer.

\section{RESULTS}

Selection and characterization of the studies

Fourteen articles were selected for your metaanalysis from PubMed, Web of Science, BIOSIS, 
SciFinder and CNKI (Figure 1 and Table 1). Four articles contain the samples of normal gastric mucosa [19-22], 14 do the correlation between REG4 expression and clinicopathological parameters of gastric cancer [2, 18$30]$, and 7 do the prognostic data of REG4 expression [18, 19, 23-26, 30].

The clinicopathological and prognostic significances of REG4 protein expression in gastric cancer

We found that REG4 expression was higher in gastric cancer than normal mucosa according to 692 cancers and 401 controls of 4 studies (Figure $2 \mathrm{~A}, p=0.0005$ ). No distinct REG4 expression was observed in between male and female cancer patients (Figure 2B, $p>0.05$ ). REG4 expression was positively linked to depth of invasion (Figure $2 \mathrm{C}, p=0.003$ ), lymph node metastasis (Figure $2 \mathrm{D}, p=0.03$ ), TNM staging (Figure $2 \mathrm{E}, p=0.04$ ), and dedifferentiation (Figure $2 \mathrm{~F}, p=0.01$ ) of gastric cancer. There was no association between REG4 expression and favorable overall survival in gastric cancer patients (Figure $2 \mathrm{G}, \mathrm{HR}=1.00,95 \% \mathrm{CI}: 0.84-1.20, p>0.05)$.

\section{Heterogeneity analysis}

To evaluate the heterogeneity, we removed a study to observe the alteration in the pooled results of remaining studies (Figure 3). For instance, the pooled OR about relationship between REG4 expression and TNM staging was remarkably decreased if Wang's study was excluded (data not shown).

The clinicopathological and prognostic significances of REG4 mRNA expression in gastric cancers

Cho's, Chen's, Cui's and DEricco's datasets were used for bioinformatics analysis. It was found that REG4 mRNA expression was lower in gastric normal tissues than cancer, even intestinal-, diffuse- and mixed-type carcinomas (Figure 4A, $p<0.05$ ). TCGA data showed that REG4 expression was negatively correlated with the histological grading of gastric cancers (Figure 4B, $p<0.05)$. As indicated in Figure 5, Kaplan-Meier plotter showed that a higher REG4 mRNA expression was positively related to both overall survival rate and

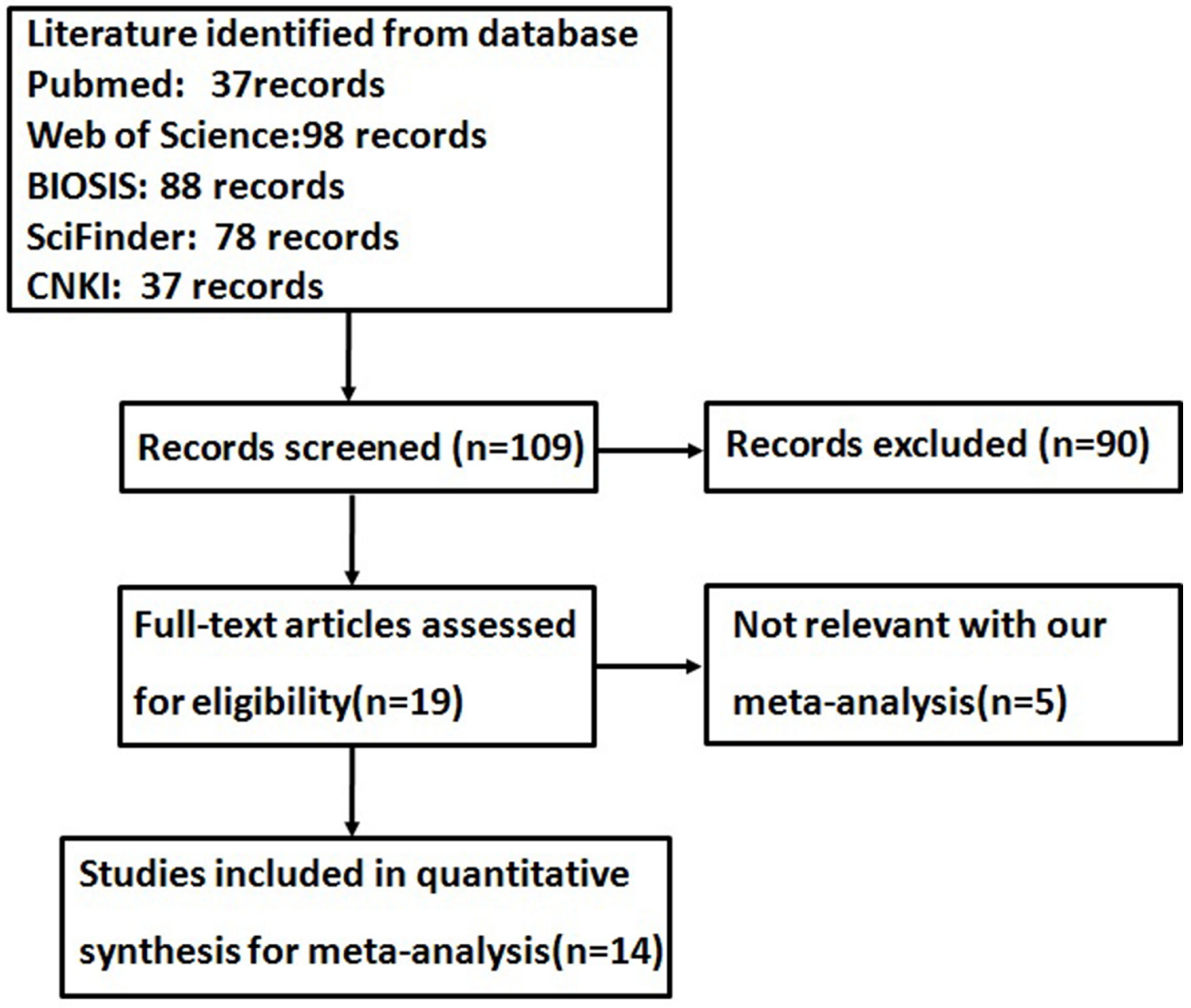

Figure 1: Flow diagram of the selection process in this meta-analysis. 
Table 1: Main characteristics of eligible studies

\begin{tabular}{|c|c|c|c|c|c|c|c|c|c|}
\hline First author & Year & Country & Ethnicity & $\mathbf{A S}$ & Cases & Control & Risk to cancer & Outcome & Quality \\
\hline Oue N & 2005 & Japan & Asian & Self-making & 143 & & & & 8 \\
\hline Mitani Y & 2007 & Japan & Asian & $R \& D$ & 161 & & & No & 8 \\
\hline Zheng HC & 2009 & Japan & Asian & $R \& D$ & 372 & 93 & Up & No & 9 \\
\hline Yamagishi H & 2009 & Japan & Asian & $R \& D$ & 63 & & & No & 8 \\
\hline Tao HQ & 2011 & China & Asian & $R \& D$ & 192 & & & $\mathrm{Neg}$ & 8 \\
\hline Moon JH & 2012 & Korea & Asian & $R \& D$ & 162 & & & No & 8 \\
\hline Suh YS & 2012 & Korea & Asian & $R \& D$ & 450 & & & $\mathrm{Neg}$ & 8 \\
\hline Wang HX & 2016 & China & Asian & $R \& D$ & 102 & & & $\mathrm{Neg}$ & 8 \\
\hline $\mathrm{Ma} \mathrm{H}$ & 2006 & China & Asian & $R \& D$ & 26 & & & & 8 \\
\hline Wu WQ & 2009 & China & Asian & $R \& D$ & 96 & & & & 7 \\
\hline Dong YL & 2012 & China & Asian & $R \& D$ & 147 & 147 & Up & & 8 \\
\hline Liu ZH & 2013 & China & Asian & $R \& D$ & 48 & & & & 7 \\
\hline Dong YL & 2013 & China & Asian & $R \& D$ & 101 & 89 & Up & & 8 \\
\hline Yan W & 2015 & China & Asian & $R \& D$ & 72 & 72 & Up & & 8 \\
\hline
\end{tabular}

AS, antibody source; Up, up-regulation; Neg, negative correlation.

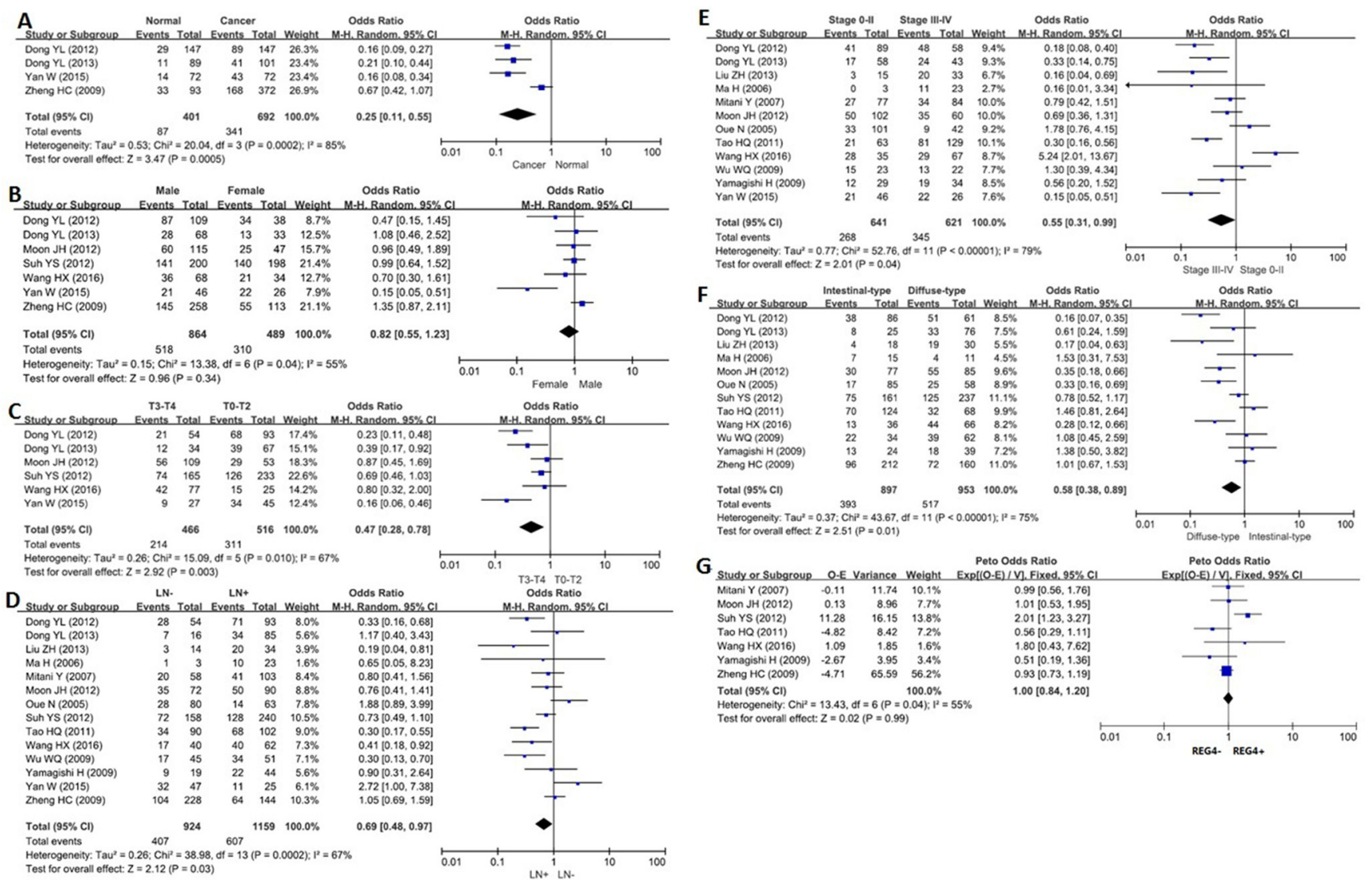

Figure 2: Forest plot for the relationship between REG4 expression and clinicopathological parameters of gastric cancer. (A) gastric carcinogenesis (cancer $v s$ normal mucosa); (B) correlation between sex and REG4 expression (male $v s$ female); (C) correlation between depth of invasion and REG4 expression (T0-2 vs T3-4); (D) correlation between lymph node metastasis (LN) and REG4 expression (LN- vs LN+); (E) correlation between TNM staging and REG4 expression (stage 0-II $v s$ III-IV); (F) correlation between differentiation and REG4 (intestinal-type $v s$ diffuse-type). (G) correlation between the prognosis and REG4 expression (REG4- vs REG4+). 
progression-free survival rate of the patients with diffusetype and N1-3 cancers or undergoing other adjuvant ( $p$ $<0.05)$, but versa for the M1 cancer patients $(p<0.05)$. Stage III, Her2-positive, and N2 cancer patients with REG4 mRNA hyperexpression had a high progressionfree survival rate than those with its hypoexpression $(p<$ $0.05)$. The similarity was seen for overall survival rate in Her2-positive cancer patients $(p<0.05)$.

\section{DISCUSSION}

Bishnupuri et al. [4, 31] found that REG4 was a potent activator of the EGFR/Akt/AP-1 signaling pathway, and protected colon cancer cells against apoptotic induction or normal intestinal crypt cells from irradiationinduced apoptosis via up-regulating the expression of Bcl2, Bcl-xl and survivin. Chen et al. [32] found that REG4 overexpression and the recombinant protein inhibited cell apoptosis, and enhanced $\mathrm{G}_{2} / \mathrm{S}$ progression, proliferation, migration and invasion with Wnt5a, p70s6k, survivin and VEGF hyperexpression and Bax hypoexpresion. Additionally, REG4 promoted migration and invasion of colon cancer cells in both autocrine and paracrine manners, which was blocked by anti-REG4 antibody [33]. Takehara et al. [34] found that REG4 knockdown caused a decrease in cell viability, and recombinant REG4 enhanced growth of pancreatic cancer cells in a dose-dependent manner. In prostate cancer cells, REG4 downregulation was found to induce p21 expression, which negatively regulated Cyclin D1 and blocked the $\mathrm{G}_{1} / \mathrm{S}$ transition [35]. Therefore, we performed a meta- and bioinformatics analysis to clarify the clinicopathological and prognostic significances of REG4 expression in gastric cancer.

Serum REG4 level was significantly higher in esophageal, gastric and pancreatic cancer patients than that in controls [36-38]. Consistent with the data about ovarian cancer, colon cancer, glioma, pancreatic cancer, gallbladder cancer, and prostate cancer [32, 38-42], we found that REG4 expression was higher in gastric cancer than normal mucosa, and positively correlated with depth of invasion, lymph node metastasis, TNM staging and differentiation of gastric cancer, suggesting that REG4 overerexpression promoted gastric carcinogenesis and subsequent progression. The higher REG4 expression
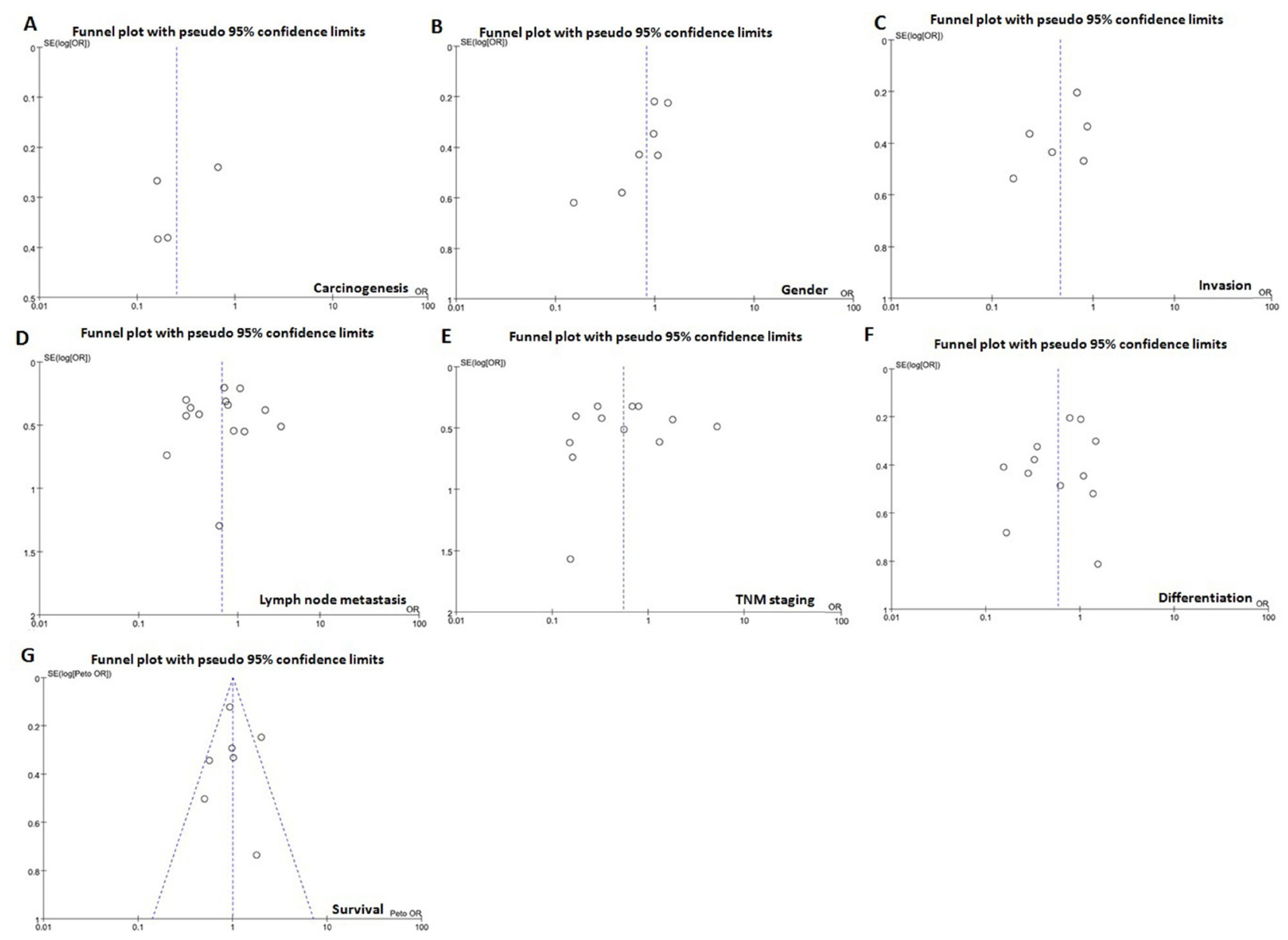

Figure 3: Funnel plot for publication bias test between REG4 expression and gastric carcinogenesis or progression. The bias was analyzed about risk degrees of REG4 expression in gastric mucosa (A) for gastric carcinogenesis. Additionally, it was tested between REG4 expression and clinicopathological features of gastric cancer, including age (B), depth of invasion $(\mathbf{C})$, lymph node metastasis (D), TNM staging (E), and differentiation $(\mathbf{F})$ and prognosis $(\mathbf{G})$. 
in diffuse- than intestinal-type carcinoma might be due to REG4 overexpression in mucinous and signet ring cell carcinoma [19]. In agreement with our finding, Lehtinen et al. [43] identified REG4 as a potential biomarker with specificity for the mucinous ovarian cancer subtype, and Chen et al. [32] found that higher REG4 mRNA expression was observed in mucinous than serous carcinomas. All 14 studies have used antiREG4 antibody from R\&D System Corp and ensured the consistence. The inconsistence might be due to immunohistochemical approaches, criteria for positive staining, statistical analysis, and subjects and samples (e.g. tissue microarray of small size).

Eguchi et al. [44] found that the patients with a higher REG4 level showed an unfavorable response to chemotherapy and radiotherapy. Reportedly, REG4 expression was positively linked to the worse prognosis of the patients with colon cancer and adenoid cystic carcinoma [39, 45]. REG4 expression might be considered as an independent factor of the worse prognosis of ovarian cancer, rectal cancer, glioma, and advanced gallbladder carcinoma as $[32,40,41,46]$. Our meta-analysis showed that REG4 expression was not linked to the prognosis of the patients with gastric cancer. Our bioinformatics analysis indicated that REG4 mRNA expression was positively associated with overall and progression-free survival rates of the patient with diffuse-type and N1-3 cancers or undergoing other adjuvant, while versa for M1 cancer. The paradoxical findings should be explained by distinct methodologies (immunohistochemistry and transcriptomic sequencing), tissue specificity and different subgroupings of gastric cancers.

In summary, there existed up-regulated REG4 expression during gastric carcinogenesis at both mRNA and protein levels. REG4 protein expression was positively correlated with aggressive behaviors of gastric cancer. REG4 mRNA was considered as a good prognostic marker of the patients with diffuse-type, N1-3 and M1 cancers or undergoing other adjuvant. The following disadvantages are mentioned in our study, including publication bias from published results being predominantly positive, subjects bias from limited kinds of the patient populations, and performance bias from data extraction of survival data using software.
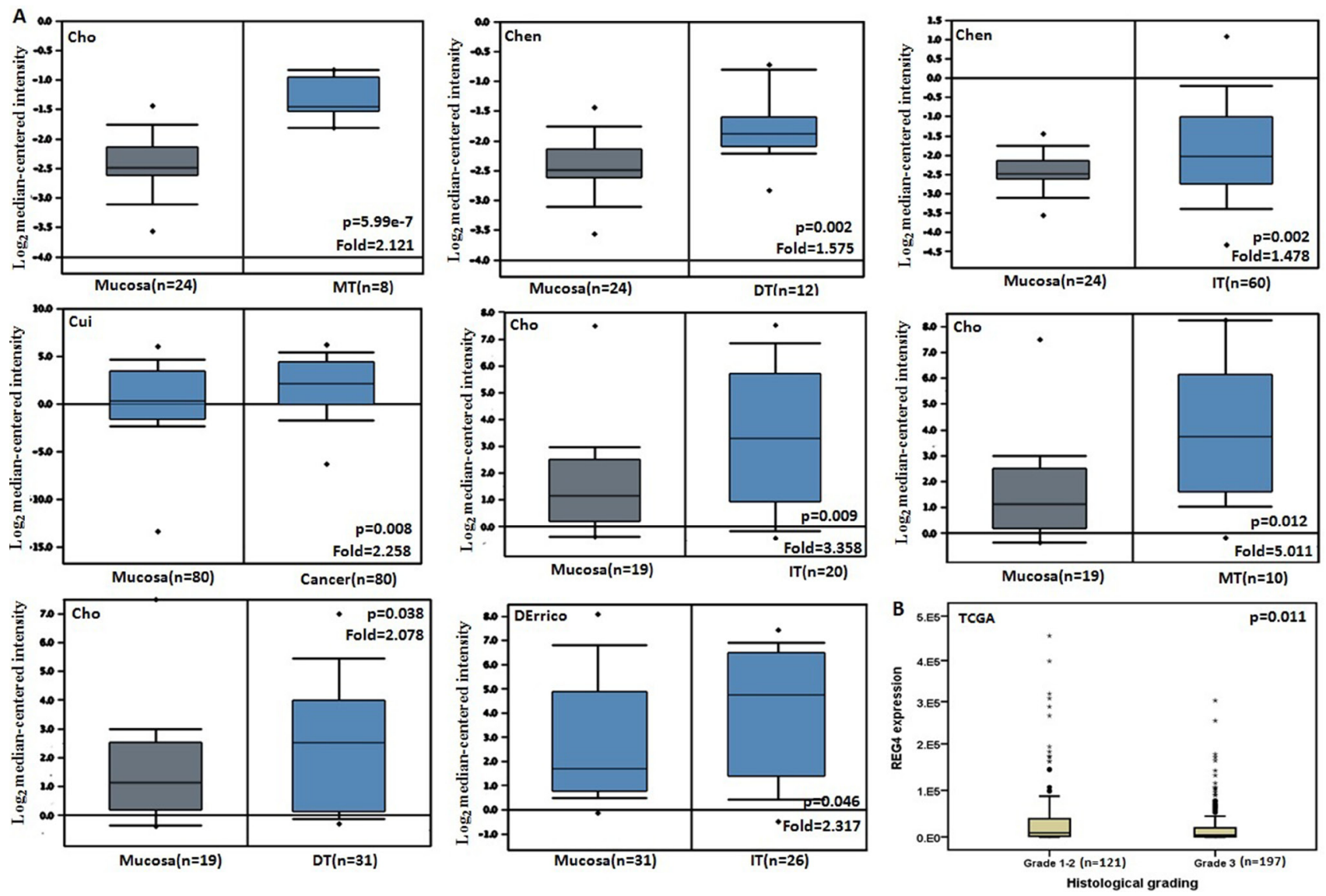

Figure 4: REG4 mRNA expression in gastric cancer and its clinicopathological significance. Cui's DErrico's, Chen's and Cho's datasets were employed for Bioinformatics analysis to analyze REG4 mRNA expression during gastric carcinogenesis. A higher REG4 mRNA expression was detectable in gastric cancer than that in normal gastric mucosa, even stratified into intestinal-(IT), diffuse(DT), and mixed-type (MT) carcinomas by Lauren's classification (A) $(p<0.05)$. TCGA database showed that REG4 mRNA was more expressed in G1-2 than $\mathrm{G} 3$ cancers $(\mathbf{B})(p<0.05)$. 


\section{MATERIALS AND METHODS}

\section{Identification of eligible studies and data extraction}

We performed a publication search using PubMed, Web of Science, BIOSIS, SciFinder and CNKI updated on March 14, 2017. The following search terms were used: (REG4 OR REG IV) AND (gastric OR stomach) AND (cancer OR carcinoma OR adenocarcinoma). Searching was done without restriction on language or publication years. Inclusion criteria for studies: (1) articles to observe the alteration in REG4 expression in gastric cancer by immunohistochemistry; (2) papers to compare REG4 expression with pathobiological behaviors and prognosis of gastric cancer by immunohistochemistry. Exclusion criteria included: (1) abstract, comment, review and meeting; (2) duplication of the previous publications; (3) Western blot, RT-PCR, cDNA microarray, or transcriptomic sequencing for REG4 expression; (4) lack of sufficient information.

\section{Data extraction}

Based on the inclusion criteria, two reviewers (HC Zheng and S Zhao) independently extracted information
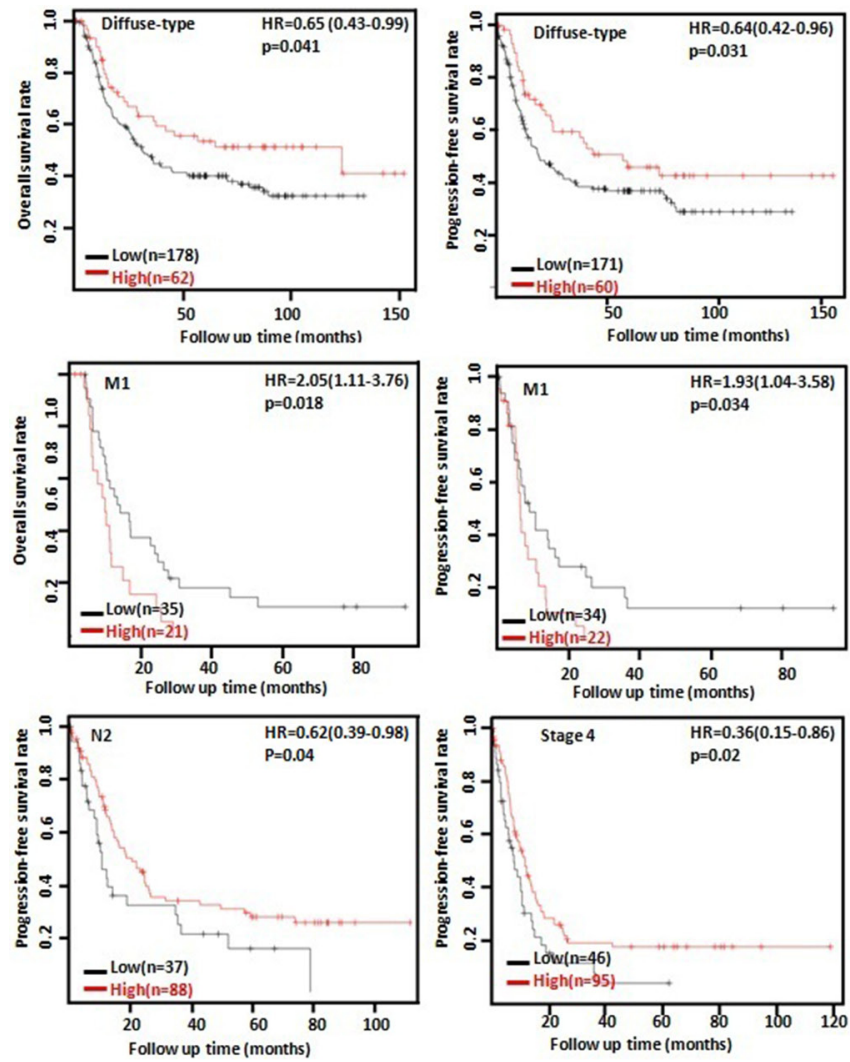

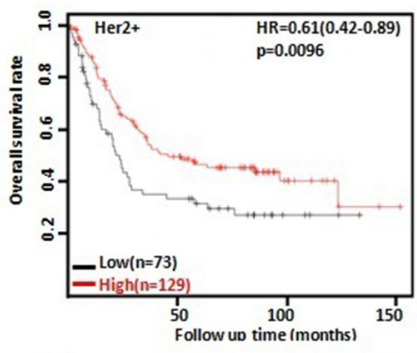

from all eligible publications. The following information was included in each study: name of first author, year of publication, country, ethnicity, antibody source, numbers of cases and controls, expression alteration, and followup outcome. Regarding survival analysis, we used Engauge Digitizer software to extract data from KaplanMeier curves and calculated the Hazard ratios (HR) and their corresponding 95\% confidence intervals (CI). Any disagreement was resolved through discussion until the two reviewers reached a consensus.

\section{Quality score assessment}

Two reviewers (HC Zheng and S Zhao) independently assessed the quality of the included studies according to Newcastle Ottawa Scale (NOS) (http://www. ohri.ca/programs /clinical_ epidemiology/oxford.htm). The scale consists of three components related to sample selection, comparability and ascertainment of outcome.

\section{Bioinformatics analysis}

The individual gene expression level of REG4 was analyzed using Oncomine (www. oncomine.org), a cancer microarray database and web-based data mining platform for a new discovery from genome-wide expression analyses. We compared the differences in REG4 mRNA
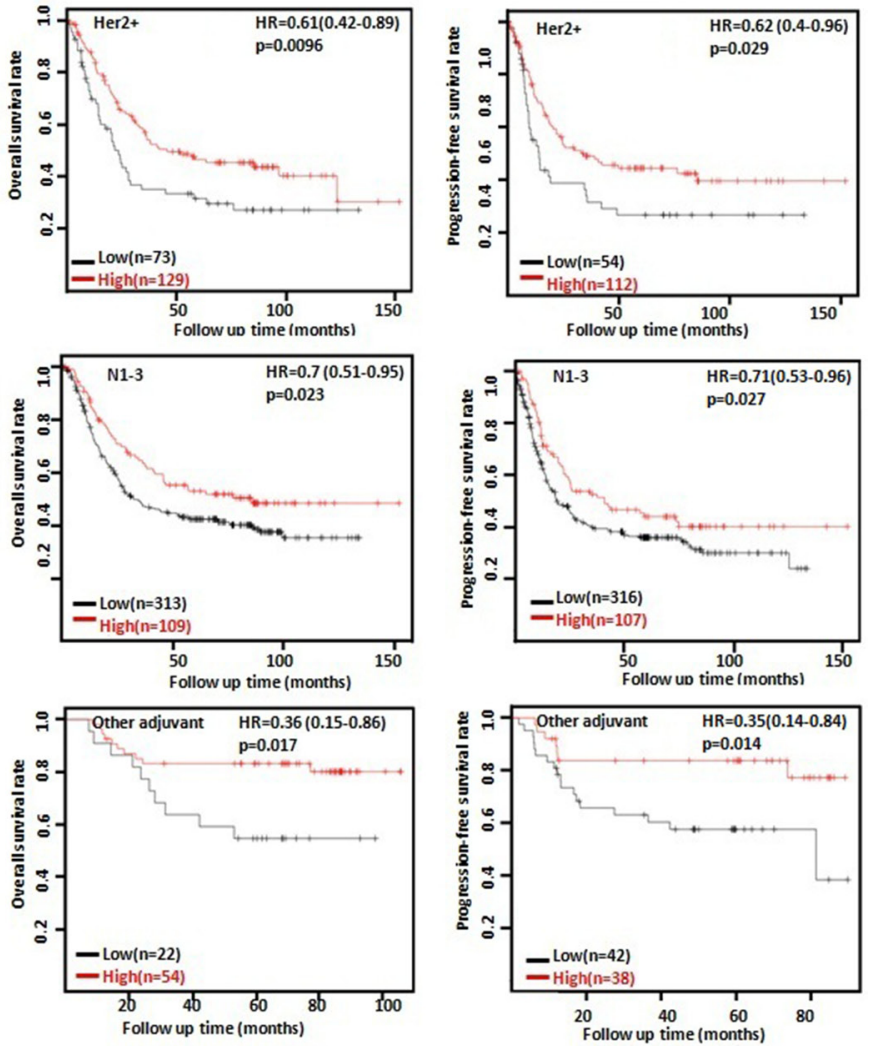

Figure 5: The prognostic significance of REG4 mRNA in the patients with gastric cancer. According to the data from Kaplan-Meier plotter, REG4 mRNA expression was positively related to either overall or progression-free survival rate of the patients with gastric cancer except M1 cancer. HR, hazard ratio. 
level between gastric normal tissue and cancer. All data were log-transformed, median centered per array, and standard deviation normalized to one per array. The expression (RNA-seqV2) and clinicopathological data of 392 gastric cancer patients were downloaded from the Cancer Genome Atlas (TCGA) database by TCGA-assembler in R software. We integrated the raw data, analyzed REG4 expression in gastric cancer, and compared it with clinicopathological and prognostic data of the patients with gastric cancer. Additionally, the prognostic significance of REG4 mRNA was also analyzed using Kaplan- Meier plotter (http://kmplot.com).

\section{Statistics analysis}

HWE was evaluated using Chi-square test in control groups of each study. Strength of association between REG4 expression and cancer risk was assessed by odds ratios with $95 \%$ confidence intervals. Statistical significance of the pooled OR was determined by $Z$ test. If there was no significant heterogeneity, the fixed effect model (Mantel-Haenszel method) would be employed. Otherwise, the random effect model (DerSimonian and Laird method) would be used excluding prognostic analysis. Heterogeneity effect was then quantified by $\mathrm{I}^{2}$ test, which was subdivided into low, moderate and high degrees of heterogeneity according to the cut-off values of $25 \%, 50 \%$ and $75 \%$ respectively. Publication bias was evaluated by funnel plot and quantified by Begg's test and Egger's test to assess funnel plot asymmetry. Metaanalyses were performed with Revman software 5.3 and data from TCGA database was dealt with SPSS 10.0 software using student $t$ test. Two-sided $p<0.05$ was considered as statistically significant.

\section{ACKNOWLEDGMENTS AND FUNDING}

This study was supported by Liaoning BaiQianWan Talents Program, Outstanding Scientific Fund of Shengjing Hospital, Natural Scientific Foundation of Liaoning Province (20170540391), Award for Liaoning Distinguished Professor, a Key Scientific and Technological Project of Liaoning Province (2015408001) and National Natural Scientific Foundation of China (81472544; 81672700).

\section{CONFLICTS OF INTEREST}

The authors have declared that no conflicts of interest exist.

\section{REFERENCES}

1. Hu Y, Pan $\mathrm{C}, \mathrm{Hu} \mathrm{J}$, Zhang S. The role of Reg IV in colorectal cancer, as a potential therapeutic target. Contemp Oncol (Pozn). 2015; 19:261-264.
2. Oue N, Mitani Y, Aung PP, Sakakura C, Takeshima Y, Kaneko M, Noguchi T, Nakayama H, Yasui W. Expression and localization of Reg IV in human neoplastic and nonneoplastic tissues: Reg IV expression is associated with intestinal and neuroendocrine differentiation in gastric adenocarcinoma. J Pathol. 2005; 207:185-198.

3. Heiskala K, Andersson LC. Reg IV is differently expressed in enteroendocrine cells of human small intestine and colon. Regul Pept. 2013; 183:27-34.

4. Bishnupuri KS, Luo Q, Murmu N, Houchen CW, Anant S, Dieckgraefe BK. Reg IV activates the epidermal growth factor receptor/Akt/AP-1 signaling pathway in colon adenocarcinomas. Gastroenterology. 2006; 130:137-149.

5. Wang H, Hu L, Zang M, Zhang B, Duan Y, Fan Z, Li J, Su L, Yan M, Zhu Z, Liu B, Yang Q. REG4 promotes peritoneal metastasis of gastric cancer through GPR37. Oncotarget. 2016; 7:27874-27888. http://doi.org/10.18632/oncotarget.8442.

6. Kawasaki Y, Matsumura K, Miyamoto M, Tsuji S, Okuno M, Suda S, Hiyoshi M, Kitayama J, Akiyama T.REG4 is a transcriptional target of GATA6 and is essential for colorectal tumorigenesis. Sci Rep. 2015; 5:14291.

7. Naito Y, Oue N, Hinoi T, Sakamoto N, Sentani K, Ohdan H, Yanagihara K, Sasaki H, Yasui W. Reg IV is a direct target of intestinal transcriptional factor CDX2 in gastric cancer. PLoS One. 2012; 7:e47545.

8. Bishnupuri KS, Sainathan SK, Bishnupuri K, Leahy DR, Luo Q, Anant S, Houchen CW, Dieckgraefe BK. Reg4induced mitogenesis involves Akt-GSK3 $\beta$ - $\beta$-CateninTCF-4 signaling in human colorectal cancer. Mol Carcinog. 2014; 53:E169-80.

9. He XJ, Jiang XT, Ma YY, Xia YJ, Wang HJ, Guan TP, Shao QS, Tao HQ. REG4 contributes to the invasiveness of pancreatic cancer by upregulating MMP-7 and MMP-9. Cancer Sci. 2012; 103:2082-2091.

10. Ma X, Wu D, Zhou S, Wan F, Liu H, Xu X, Xu X, Zhao Y, Tang M. The pancreatic cancer secreted REG4 promotes macrophage polarization to M2 through EGFR/AKT/ CREB pathway. Oncol Rep. 2016; 35:189-196.

11. Nanakin A, Fukui H, Fujii S, Sekikawa A, Kanda N, Hisatsune H, Seno H, Konda Y, Fujimori T, Chiba T. Expression of the REG IV gene in ulcerative colitis. Lab Invest. 2007; 87:304-314.

12. Oue N, Kuniyasu H, Noguchi T, Sentani K, Ito M, Tanaka S, Setoyama T, Sakakura C, Natsugoe S, Yasui W. Serum concentration of Reg IV in patients with colorectal cancer: overexpression and high serum levels of Reg IV are associated with liver metastasis. Oncology. 2007; 72:371380 .

13. Zhang Y, Lai M, Lv B, Gu X, Wang H, Zhu Y, Zhu Y, Shao L, Wang G. Overexpression of Reg IV in colorectal adenoma. Cancer Lett. 2003; 200:69-76.

14. Lasserre $\mathrm{C}$, Colnot $\mathrm{C}$, Bréchot $\mathrm{C}$, Poirier F. HIP/PAP gene, encoding a C-type lectin overexpressed in primary liver cancer, is expressed in nervous system as well as in intestine 
and pancreas of the postimplantation mouse embryo. Am J Pathol. 1999; 154:1601-1610.

15. Lasserre C, Christa L, Simon MT, Vernier P, Bréchot C. A novel gene (HIP) activated in human primary liver cancer. Cancer Res. 1992; 52:5089-5095.

16. Kimura N, Yonekura H, Okamoto H, Nagura H. Expression of human regenerating gene mRNA and its product in normal and neoplastic human pancreas. Cancer. 1992; 70:1857-1863.

17. Ohara S, Oue N, Matsubara A, Mita K, Hasegawa Y, Hayashi T, Usui T, Amatya VJ, Takeshima Y, Kuniyasu H, Yasui W. Reg IV is an independent prognostic factor for relapse in patients with clinically localized prostate cancer. Cancer Sci. 2008; 99: 1570-1577.

18. Mitani Y, Oue N, Matsumura S, Yoshida K, Noguchi T, Ito M, Tanaka S, Kuniyasu H, Kamata N, Yasui W. Reg IV is a serum biomarker for gastric cancer patients and predicts response to 5-fluorouracil-based chemotherapy. Oncogene. 2007; 26:4383-4393.

19. Zheng HC, Xu XY, Yu M, Takahashi H, Masuda S, Takano Y. The role of Reg IV gene and its encoding product in gastric carcinogenesis. Hum Pathol. 2010; 41:59-69.

20. Dong YL, Zhou SY, Zhang J. Expression of Reg IV and EGFR in gastric cancer. Mod Oncol. 2012; 20:2098-2101.

21. Dong YL, Zhou SY, Zhang J. Expression and correlation of Reg IV, MMP-9 and CD34 in human gastric carcinoma. Chin J Coal Ind Med. 2013; 16:1778-1782.

22. Yan W, Xu XM, Tang J, Lai X, Zhao JJ. Expressions and correlation analysis of Reg IV and CCL17 in gastric cancer. Prog Mod Biomed. 2015; 26:5063-5066.

23. Yamagishi H, Fukui H, Sekikawa A, Kono T, Fujii S, Ichikawa K, Tomita S, Imura J, Hiraishi H, Chiba T, Fujimori T. Expression profile of REG family proteins REG Ialpha and REG IV in advanced gastric cancer: comparison with mucin phenotype and prognostic markers. Mod Pathol. 2009; 22:906-913.

24. Tao HQ, He XJ, Ma YY, Wang HJ, Xia YJ, Ye ZY, Zhao ZS. Evaluation of REG4 for early diagnosis and prognosis of gastric cancer. Hum Pathol. 2011; 42:1401-1409.

25. Moon JH, Fujiwara Y, Nakamura Y, Okada K, Hanada H, Sakakura C, Takiguchi S, Nakajima K, Miyata H, Yamasaki M, Kurokawa Y, Mori M, Doki Y. REGIV as a potential biomarker for peritoneal dissemination in gastric adenocarcinoma. J Surg Oncol. 2012; 105:189-194.

26. Suh YS, Lee HJ, Jung EJ, Kim MA, Nam KT, Goldenring JR, Yang HK, Kim WH. The combined expression of metaplasia biomarkers predicts the prognosis of gastric cancer. Ann Surg Oncol. 2012; 19:1240-1249.

27. Ma H, Mei F, Ma QL, Zhang HJ, Zhou DS. Expression of Reg IV protein in human gastric carcinoma and its clinical significance. Acta Acad Med Mil Tert. 2006; 5:441-443.

28. Liu ZH, Ni YP, Huang QG, Xie LX, Shen JH. Significance of Reg IV expression in gastric carcinoma. Mod Oncol. 2013; 21:1550-1551.

29. Wu WQ, He WJ, Wang HJ, Ma YY. The role of REG4 on diagnosis and predicting prognosis of gastric cancer. J Oncol. 2009; 15:925-927.
30. Wang H, Hu L, Zang M, Zhang B, Duan Y, Fan Z, Li J, Su L, Yan M, Zhu Z, Liu B, Yang Q. REG4 promotes peritoneal metastasis of gastric cancer through GPR37. Oncotarget. 2016; 7:27874-27888. http://doi.org/10.18632/oncotarget.8442.

31. Bishnupuri KS, Luo Q, Sainathan SK, Kikuchi K, Sureban SM, Sabarinathan M, Gross JH, Aden K, May R, Houchen CW, Anant S, Dieckgraefe BK. Reg IV regulates normal intestinal and colorectal cancer cell susceptibility to radiation-induced apoptosis. Gastroenterology. 2010; 138:616-626.

32. Chen S, Gou WF, Zhao S, Niu ZF, Zhao Y, Takano Y, Zheng $\mathrm{HC}$. The role of the REG4 gene and its encoding product in ovarian epithelial carcinoma. BMC Cancer. 2015; 15: 471.

33. Rafa L, Dessein AF, Devisme L, Buob D, Truant S, Porchet $\mathrm{N}$, Huet G, Buisine MP, Lesuffleur T. REG4 acts as a mitogenic, motility and pro-invasive factor for colon cancer cells. Int J Oncol. 2010; 36:689-698.

34. Takehara A, Eguchi H, Ohigashi H, Ishikawa O, Kasugai T, Hosokawa M, Katagiri T, Nakamura Y, Nakagawa H. Novel tumor marker REG4 detected in serum of patients with resectable pancreatic cancer and feasibility for antibody therapy targeting REG4. Cancer Sci. 2006; 97:1191-1197.

35. Liu CM, Hsieh CL, He YC, Lo SJ, Liang JA, Hsieh TF, Josson S, Chung LW, Hung MC, Sung SY. In vivo targeting of ADAM9 gene expression using lentivirus-delivered shRNA suppresses prostate cancer growth by regulating REG4 dependent cell cycle progression. PLoS One. 2013; 8:e53795.

36. Kobayashi Y, Niwa Y, Tajika M, Kawai H, Kondo S, Hara K, Mizuno N, Hijioka S, Sawaki A, Matsuo K, Nakagawa H, Nakamura Y, Yamao K. Serum tumor antigen REG4 as a useful diagnostic biomarker in gastric cancer. Hepatogastroenterology. 2010; 57:1631-1634.

37. Oue N, Noguchi T, Anami K, Sentani K, Sakamoto N, Uraoka N, Wakamatsu Y, Sasaki H, Yasui W. Serum concentration and expression of Reg IV in patients with esophageal cancer: Age-related elevation of serum Reg IV concentration.Oncol Lett. 2011; 2:235-239.

38. Takayama R, Nakagawa H, Sawaki A, Mizuno N, Kawai $\mathrm{H}$, Tajika M, Yatabe Y, Matsuo K, Uehara R, Ono K, Nakamura Y, Yamao K. Serum tumor antigen REG4 as a diagnostic biomarker in pancreatic ductal adenocarcinoma. J Gastroenterol. 2010; 45:52-59.

39. Zhu X, Han Y, Yuan C, Tu W, Qiu G, Lu S, Lu H, Peng Z, Zhou C. Overexpression of Reg4, alone or combined with MMP-7 overexpression, is predictive of poor prognosis in colorectal cancer. Oncol Rep. 2015; 33:320-328.

40. Wang Q, Deng J, Yuan J, Wang L, Zhao Z, He S, Zhang Y, $\mathrm{Tu}$ Y. Oncogenic reg IV is a novel prognostic marker for glioma patient survival. Diagn Pathol. 2012; 7:69.

41. Tamura H, Ohtsuka M, Washiro M, Kimura F, Shimizu H, Yoshidome H, Kato A, Seki N, Miyazaki M. Reg IV expression and clinicopathologic features of gallbladder carcinoma. Hum Pathol. 2009; 40:1686-1692. 
42. Hayashi T, Matsubara A, Ohara S, Mita K, Hasegawa Y, Usui T, Arihiro K, Norimura S, Sentani K, Oue N, Yasui W. Immunohistochemical analysis of Reg IV in urogenital organs: Frequent expression of Reg IV in prostate cancer and potential utility as serum tumor marker. Oncol Rep. 2009; 21:95-100.

43. Lehtinen L, Vesterkvist P, Roering P, Korpela T, Hattara L, Kaipio K, Mpindi J, Hynninen J, Auranen A, Davidson B, Haglund C, Iljin K, Grenman S, et al. REG4 is highly expressed in mucinous ovarian cancer: a potential novel serum biomarker. PLoS One. 2016; 11:e0151590.

44. Eguchi H, Ishikawa O, Ohigashi $\mathrm{H}$, Takahashi $\mathrm{H}$, Yano M, Nishiyama K, Tomita Y, Uehara R, Takehara
A, Nakamura Y, Nakagawa H. Serum REG4 level is a predictive biomarker for the response to preoperative chemoradiotherapy in patients with pancreatic cancer. Pancreas. 2009; 38:791-798.

45. Sasahira T, Oue N, Kirita T, Luo Y, Bhawal UK, Fujii K, Yasui W, Kuniyasu H. Reg IV expression is associated with cell growth and prognosis of adenoid cystic carcinoma in the salivary gland. Histopathology. 2008; 53:667-675.

46. He HL, Lee YE, Shiue YL, Lee SW, Lin LC, Chen TJ, Wu TF, Hsing CH, Huang HY, Wang JY, Li CF. Overexpression of REG4 confers an independent negative prognosticator in rectal cancers receiving concurrent chemoradiotherapy. J Surg Oncol. 2014; 110:1002-1010. 